\title{
Persembahan yang Layak di hadapan Tuhan Ditinjau dari Kejadian 4:1-16 Perspektif Teori Behavioristik
}

\author{
Elda Elmi, Grace Carolina Sambano, Enjel Somakila, \\ Grace Gloria Kadaang
}

\begin{abstract}
Abstrak. Persembahan merupakan bentuk ucapan syukur. Persembahan yang dilakukan tidak bisa dipisahkan dari ajaran Alkitab, baik dalam Perjanjian Lama maupun Perjanjian Baru. Bentuk persembahan tidak hanya berbicara dengan uang yang diberikan tapi juga persembahan dapat diberikan dalam bentuk natura (hasil panen/hasil ternak). Selain itu persembahan juga dapat berbentuk materi dan persembahan yang hidup ialah diri sendiri. Berkat yang dimiliki itu semua pemberian Tuhan dan bagaimana umat Allah harus memberikan persembahan yang terbaik kepada Tuhan. Persembahan yang terbaik berarti memberikan persembahan yang tulus dari hati dan tidak memandang persembahan orang lain. Apa yang Tuhan berikan itu sesuai dengan kebutuhan umat-Nya. Tuhan tidak memandang seberapa besar atau banyak yang diberikan sebagai persembahan. Penelitian membuktikan bahwa mahasiswa mata kuliah Psikologi Umum kelompok B memahami tentang pemberian persembahan yang layak di hadapan Tuhan dalam Kejadian 4:1-16, jadi mahasiswa akan berpartisipasi dalam memberikan persembahan dengan motivasi yang tepat dan kualitas terbaik untuk Allah. Dengan demikian hasil penelitian ini menunjukkan bahwa hasilnya sesuai dengan apa yang diharapkan peneliti sebelumnya.
\end{abstract}

Kata Kunci: Ajaran, Persembahan, Alkitab

\section{PENDAHULUAN}

Manusia pada hakikatnya adalah makhluk yang bersifat spritual. Oleh karena itu, manusia mampu menanggapi hal-hal yang secara rohani. Manusia selalu berusaha untuk berhubungan dengan yang Ilahi. Sehingga hubungan dengan yang Ilahi tersebut dalam bentuk ibadah. Konsep ibadah baik dalam Perjanjian Lama maupun Perjanjian Baru memiliki konsep yang sama. Kata Ibrani abad dan Yunani latreia pada mulanya menyatakan pekerjaan seorang budak. Dan dalam rangka mempersembahkan 'ibadat' kepada Allah, maka para hamba-Nya harus meniarap, sebagai ungkapan rasa takut penuh hormat, kekaguman dan ketakjuban penuh puja. Konsep inilah yang mendasari tindakan seseorang dalam setiap kegiatan memberikan korban persembahan dalam setiap ibadah. ${ }^{1}$

Demikian juga berkaitan dengan pelaksanaan ibadah yang dilakukan oleh orang percaya kepada Tuhan Yesus. Persembahan yang dilakukan oleh manusia dan diberikan

${ }^{1}$ J. D. Douglas, Ensiklopedia Alkitab Masa Kini Jilid I (Jakarta: Yayasan Komunikasi Bina Kasih/OMF, 1992), 409. 
kepada Tuhan sebagai korban syukur merupakn bagian dari ibadah. Persembahan tidak bisa dipisahkan dari ibadah. Hal ini karena persembahan bukan hanya sekedar simbol untuk memberi dengan apa yang dimiliki baik itu berupa uang, barang atau lainnya. Tetapi hal yang terbaik dari persembahan ialah persembahan yang diberikan kepada Tuhan Yesus harus dilandasi dengan iman atau dasar yang benar tanpa memandang pemberian orang lain atau dengan tujuan yang berbeda. Hampir semua bentuk ibadah yang dilakukan mulai dari anak sekolah minggu, remaja, pemuda, kaum ibu, kaum bapak, lansia, ibadah hari Minggu, dan ibadah lainnya melakukan persembahan sebagai korban syukur telah menjadi bagian dalam liturgi ibadah. Tetapi pemberian itu harus dipahami secara benar dan sungguh-sungguh.

Persembahan dapat dimaknai sebagai ungkapan yang mendalam dari manusia dalam hubungannya kepada Tuhan. Makna tersebut berdasar kepada arti dari ibadah itu sendiri. Ibadah Kristen adalah keikutsertaan umat di dalam tindakan Imamat Kristus demi kepentingan manusia sendiri, sebagai ajakan kepada umat menjadi korban korban yang hidup di dalam kehidupannya. ${ }^{2}$ Salah satu bagian terpenting dari kedewasaan kerohanian ialah bagaimana umat Allah memahami kuasa dan relevasi Firman Tuhan bagi orang percaya dalam setiap aspek kehidupan. Sepanjang kehidupan manusia harus terus belajar menuju pada kesempurnaan karena Firman Tuhan mengandung kebenaran. Setiap Firman Tuhan dipelajari maka banyak hal yang dapat diperoleh dari kebenaran dan ajaran-ajaran Tuhan.

Persembahan yang dilakukan oleh orang Kristen saat ini tidak dapat terlepas dari ajaran Alkitab baik Perjanjian Lama dan Perjanjian Baru. Ada banyak kisah yang dapat dipelajari mengenai persembahan yang diberikan kepada Tuhan Yesus. Dalam Perjanjian Baru korban persembahan masih dilaksanakan, bahkan Tuhan Yesus mempersembahkan korban pada Paskah terakhir. Kristus dikatakan Domba Allah yang disembelih, darahNya yang suci meniadakan dosa dunia. ${ }^{3}$ Dalam Kitab Perjanjian Lama kisah yang dapat dipelajari mengenai korban persembahan yaitu Nuh, Abraham dan bangsa Israel meneruskan pola ibadah yang disertai korban tersebut. Selain itu dapat dilihat kisah di Kejadian 4:1-16, memberikan penjelasan bahwa jauh sebelum gereja ada, keturunan Adam dan Hawa dalam hal ini Kain dan Habel telah melaksanakan korban yang dipersembahkan kepada Tuhan.

Sebagai umat yang telah dijadikan baru, maka harus mempersembahkan diri kepada Tuhan. Inilah yang dimaksudkan oleh Rasul Paulus, "...supaya kamu mempersembahkan tubuhmu sebagai persembahan yang hidup, yang kudus dan yang berkenan kepada Allah..." Roma 12:1. Melihat bahwa korban persembahan berkaitan dengan ibadah, maka sikap penyerahan hidup kepada Tuhan menjadi kunci dari semua persembahan.

Namun sampai saat ini, masih ada umat Tuhan yang belum begitu menyadari betapa pentingnya memberikan persembahan yang benar. Demikian juga, masih dijumpai anak-anak Tuhan yang secara ekonomi sangat mampu, namun belum dapat memberikan persembahan dengan baik. Mereka hanya sekedar memberi persembahan, bahkan persembahan tersebut tidak memiliki nilai berarti bagi diri mereka. Masih kurangnya kesadaran umat Tuhan akan semua yang ada padanya adalah milik Tuhan. Persembahan seharusnya menjadi milik Tuhan dan untuk kegiatan pekerjaan Tuhan secara menyeluruh. Ada jemaat yang senang mendapat pujian karena mereka memberi persembahan lebih

${ }^{2}$ Peter Salim dan Yenny Salim, kamus Bahasa Indonesia Kontemporer (Jakarta, Kodern English Press. 1991, 1361).

${ }^{3}$ J. D. Douglas, Ensiklopedia Alkitab Masa Kini Jilid I (Jakarta: Yayasan Komunikasi Bina Kasih/OMF, 1992), 581. 
besar dari yang lain. Ada juga yang beranggapan ketika mereka memberi persembahan yang besar, mereka juga akan menerima lebih besar lagi. Hal tersebut seperti yang diungkapkan oleh Larry Burkett dalam bukunya 'Mengatar Keuangan dengan Bijak.'4

Dengan demikian, penulis dapat membuat suatu peniliatan berkaitan dengan memberi persembahan yang benar sesuai dengan Alkitab yang ditinjau dari Kejadian 4:116 sebagai sumber dasarnya. Sehingga melalui penelitian ini yang menggunakan teori behavioristik dapat memberikan perubahan tingkah laku kepada pembaca terutama kepada mahasiswa mata kuliah Psikologi Umum kelompok B.

\section{KAJIAN TEORI}

Persembahan berasal dari kata "sembah" yang berarti penyataan hormat dan khidmat. ${ }^{5}$ Persembahan yang dilakukan harus diberikan dengan benar sesuai dengan firman Tuhan dan tertuju kepada Tuhan Yesus. Namun masih ada beberapa umat Tuhan yang tidak memahami pemberian korban syukur itu. Sehingga perlunya pembelajaran dari diri masing-masing yang akan menciptakan perubahan dalam dirinya. Proses perubahan itu memang memerlukan waktu yang cukup banyak, karena untuk mengalami perubahan yang baik itu memerlukan pengorbanan besar dan komitmen. Ada beberapa teori pembelajaran yang dapat dilakukan salah satunya Teori Ivan P. Pavlov. Teori Pembelajaran Ivan P. Pavlov ialah suatu organisme belajar mengaitkan atau mengasosiasikan stimuli. Dalam pengondisian klasik, stimulus netral (seperti melihat seseorang) diasosiasikan dengan stimulus yang bermakna (seperti makanan) dan menimbulkan kapasitas untuk mengeluarkan respons yang sama. ${ }^{6}$ Dengan kata lain, teori Ivan P. Pavlov dikenal dengan sebutan psikologi reflek, yaitu pendekatan yang lebih menekankan kepada berbagai hal yang berbentuk perilaku yang sifatnya reflek. ${ }^{7}$ Umat Tuhan yang masih memberikan persembahan dengan tidak benar atau tidak sesuai firman Tuhan dapat mengalami perubahan melalui teori Ivan P. Pavlov ini. Dimana umat Tuhan ketika telah menerima penjelasan materi mengenai pemberian persembahan yang layak di hadapan Tuhan sesuai dengan Kitab Kejadian 4:1-16 dapat mengalami perubahan tingkah laku dengan pola pikir mereka untuk melihat kebenaran.

Jauh sebelum lahirnya gereja, praktek persembahan yang telah dilakukan pada masaAbraham. Upacara persembahan kurban, merupakan praktek kuno, guna menjalin hubungan dengan Allah lewat persembahan yang disampaikan melalui Iman, lalu dilembagakan ke dalam ketentuan Hukum Taurat serta dikaitkan dengan Rumah Tuhan dan jabatan ke-Imaman (Kel. 29; Bil. 18; Ibr. 8:1-4). Pada dasarnya, persembahan kurban merupakan usaha untuk menjalin kembali hubungan dengan Tuhan sebagai "persembahan yang harum" dan "pengakuan dosa serta menyenangkan hati Allah" (Kel. 29:25). ${ }^{8}$

Persembahan tidak bisa terlepas dari Alkitab. Dalam Alkitab terdapat ajaran mengenai persembahan yang layak dihadapan Tuhan baik dalam Perjanjian Lama maupun Perjanjian Baru. Pada Kitab Kejadian 4:1-16 yang menceritakan tentang persembahan Kain dan Habel. Perikop ini membahas tentang pembunuhan Habel yang

${ }^{4}$ Larry Burkett, Mengatur Keuangan dengan Bijak (Bandung: Yayasan Kalam Hidup, 1993), 308.

${ }^{5}$ G. C. van Niftrik, dan B. J. Boland, Dogmatika Masa Kini (Jakarta: BPK Gunung Mulia, 2009), 243.

${ }^{6}$ Firmina Angela Nai, Teori Belajar dan Pembelajaran Implementasi dalam Pembelajaran Bahasa Indonesia (Yogyakarta: Penerbit Deepublish, 2017), 16.

${ }^{7}$ M. Andi Setiawan, Pendekatan-Pendekatan Konseling Teori dan Aplikasi (Yogyakarta: Penerbit Deepublish, 2017), 33.

${ }^{8}$ G. C. van Niftrik, B. J. Boland, Dogmatika Masa Kini (Jakarta: BPK Gunung Mulia, 2009), 245. 
dilakukan oleh Kain, kakaknya sendiri. Kain membunuh Habel karena ia sakit hati, persembahannya tidak diindahkan oleh Tuhan. ${ }^{9}$ Tidak Diindahkan sama halnya dengan diacuhkan yang artinya tidak diperhatikan atau diperhitungkan. ${ }^{10}$ Katakanlah, Habel adalah korban balas dendam. TUHAN mengutuk Kain. Kain dikejar rasa takut akan ancaman balas dendam. Pekerjaan Kain dan Habel berbeda-beda, agar mereka bisa tukar barang antar satu sama lain bilamana diperlukan. Dalam kehidupan bersama, setiap anggota saling membutuhkan dan saling mengasihi dengan cara saling bertukar untuk memenuhi kebutuhan masing-masing. Namun, hal tersebut tidak berlaku pada Kain dan Habel. Tafsiran Alkitab Sabda mengatakan pada ayat 3-5 bahwa persembahan Habel diterima oleh Tuhan karena dia menghampiri Allah dengan iman yang benar dan pengabdian kebenaran(Ibr. 11:4; 1 Yoh. 3:12; Yoh. 4:23-24). Persembahan Kain ditolak karena ia tidak memiliki Iman yang taat dan perbuatannya jahat (Kej. 4:6-7; 1 Yoh. 3:12). ${ }^{11}$ Allah berkenan atas persembahan dan ucapan syukur hanya apabila kita sungguhsungguh berusaha hidup benar sesuai dengan kehendak-Nya.

Kain adalah yang pertama yang memberikan suatu persembahan kepada Tuhan. Tidak ada yang secara bawaan lebih rendah antara suatu persembahan biji-bijian dibanding persembahan binatang. Apa yang penting adalah dalam iman dari si pemberi korban, bukan korbannya itu sendiri. ${ }^{12}$ Awal mula adanya persembahan ilah harus ada darah yang tercurah untuk menutup dosa dan hal itu merupakan pemberian korban syukur. ${ }^{13}$ Musa mengajarkan cara memberikan persembahan dari binatang sebagai "perdamaian" dengan TUHAN. semua persembahan itu sebagai pembayar "utang darah" manusia karena dosa. ${ }^{14}$ Kini, doa Kristen membuat sikap orang bersifat makin rohani, sebab kurban persembahan sudah tidak ada lagi; orang sudah tahu bahwa tanpa dukungan kurban persembahan pun Allah sudi mendengar orang yang memohon itu. doa Kristen dicangkokkan pada kehidupannya, dan bukan lagi perkara asing baginya. Lalu, pengetahuannya akan Allah berikan bertambah terus, sehingga bukan hanya kurban persembahan, melainkan juga sokongan-sokongan jasmani lainnya yang masih ada padanya menjadi hilang dan ibadahnya semakin bersifat rohani. ${ }^{15}$

Sejarah munculnya istilah "Persembahan" dimulai ketika "Kain dan Habel" mempersembahkan persembahannya kepada Allah (Kej. 4:1-16). Kedua kakak beradik ini, melakukan pekerjaan yang berbeda. Kain menjadi petani dimana ia mengerjakan tanah, sedangkan Habel jadi gembala. Pada suatu peristiwa, keduanya membawa hasil dari pekerjaannya masing-masing untuk dipersembahkan sebagai persembahan kepada Allah. Kain membawa hasil pekerjaannya yakni hasil bumi, sedangkan Habel mempersembahkan anak dulung kambing dombanya. Allah tidak berkenan akan Kain dan persembahannya, tetapi Habel persembahannya dikenan Allah. Sebenarnya letak persoalannya bukan antara hasil tanah dan domba, namun pada keadaan batin mereka yang menyerahkan. Habel mempersembahkan hasil ternaknya dengan penuh iman, sedangkan Kain tidak. Selanjutnya bila membaca Ibrani 11:4 jelas dikatakan 'Karena iman Habel telah mempersembahkan kepada Allah korban yang lebih baik daripada persembahan Kain.' Adapun pertanda yang dapat dipahami bahwa persembahan Habel diterima sedangkan persembahan Kain tidak adalah korban Habel asapnya membumbung

\footnotetext{
${ }^{9}$ Nico Gara, Menafsirkan Alkitab Secara Praktis (Jakarta: BPK Gunung Mulia, 2002), 24.

${ }^{10}$ Kamus Besar Bahasa Indonesia "Diindahkan; diacuhkan."

${ }^{11}$ Alkitab Sabda Kejadian 4:1-16.

${ }^{12}$ Tafsiran Alkitab UTLEY (Kej. 4:1-8).

${ }^{13}$ Heri I. Budiyanto, Berbagai Terang Kristus (Jakarta: Pustaka Ekklesia, 2017), 78

${ }^{14}$ Ibid., 79.

${ }^{15}$ A. C. Kruyt, Keluar dari Agama Suku Masuk ke Agama Kristen (Jakarta: BPK Gunung Mulia,
} 2014), 112. 
ke atas sedangkan persembahan Kain asapnya tidak naik (Bdk. Ibr. 11:4). Karena persembahan Kain tidak berkenan kepada Allah, iapun menjadi iri dan membenci adiknya Habel sampai-sampai dengan tega membunuh adiknya itu. sebagai akibat atau hukuman Allah atas kejahatan Kain, iapun diusir sebagai pengembara dan pelarian di Bumi. ${ }^{16}$

Meskipun dalam surat ditegaskan bahwa persembahan sempurna hanyalah persembahan pribadi Yesus Kristus, tidak berarti bahwa perjuangan orang Kristen tidak punya arti apa-apa. Justru karena Iman akan Yesus Kristus maka persembahan orang Kristen dipersatukan dalam persembahan Yesus Kristus dan menemukan arti serta nilainya dalam persembahan tersebut. Maka ibadat bersama orang Kristen juga mencerminkan kekayaan ibadat bersama Yesus Kristus. Orang Kristen bersama dengan Imam Besar mereka mempersembahkan persembahan hidup itu sehingga berkenan kepada Allah. ${ }^{17}$ Dalam Yesus Kristus orang Kristen menemukan ibadah baru, yakni persembahan hidup bersama Kristus. Kurban persembahan binatang tidak lagi relevan, karena pada dasarnya persembahan yang sesungguhnya adalah persembahan hidup manusia sendiri. Persembahan yang sejati itu muncul karena sikap taat manusia baik secara pribadi mapun bersama kepada Allah. ${ }^{18}$

Persembahan adalah suatu pemberian kepada orang yang terhormat. Kata persembahan juga dapat diartikan dengan pembaktian diri, penyerahan diri, penghormatan, pengabdian atau minta perlindungan dari seseorang yang dianggap lebih kuat dari dirinya sendiri. ${ }^{19}$ Ketika seseorang menyerahkan persembahan, di dalamnya terkandung suatu pengakuan bahwa Tuhan Yesus telah memelihara kita dengan setia dan sempurna. Persembahan yang benar seharusnya diawali dengan kesediaan mempersembahkan diri dan hidup sepenuhnya kepada Tuhan, itulah persembahan yang hidup dan kudus. Seiring dengan hal itu, ketika orang Kristen hadir atau mengikuti ibadah di tengah-tengah gereja, di samping menyediakan hati dan pikiran untuk bersekutu dengan Tuhan, umat juga harus mempersiapkan persembahan yang akan diserahkan kepada Tuhan. Hal ini juga ditekankan dalam Ul. 16:16-17 dimana dikatakan 'Tuhan mengundang umat untuk menghadap hadirat Tuhan, tetapi jangan dengan tangan hampa.' Demikian juga dengan apa yang tertulis dalam Maz. 96:7-8 'Kepada Tuhan, hai suka-suka bangsa, kepada Tuhan sajalah kemuliaan dan kekuatan! Berilah kepada Tuhan kemuliaan nama-Nya, bawalah persembahan dan masuklah ke pelataran-Nya. ${ }^{20}$ Persembahan yang dimaksud adalah persembahan yang telah dipersiapkan atau dikhususkan. ${ }^{21}$

Dari penjelasan teori di atas mengenai asal mulanya dan bentuk persembahan yang diindahkan Tuhan dan yang tidak diindahkan, penulis memilih cerita persembahan Kain dan Habel yang terdapat di Kejadian 4:1-16, karena pada ayat tersebut dapat dilihat persembahan seperti apa yang diindahkan Tuhan dan tidak diindahkan. Sedangkan sampai saat ini orang-orang yang Kristiani mengikuti ibadah dan tidak pernah terlepas dengan namanya persembahan. Memberi persembahan merupakan suatu kewajiban dan kearusan bagi semua orang Kristen, karena persembahan merupakan tanda ucapan syukur mengenai pemberian Tuhan kepada umat-Nya baik itu berkat secara jasmani maupun secara rohani. Karena persembahan ini diberikan kepada Tuhan, sehingga persembahan

\footnotetext{
${ }^{16}$ C. Barth, Teologi PL I (Jakarta: BPK Gunung Mulia, 1988), 79.

${ }^{17}$ St. Darmawijaya, Pr., Seluk Beluk Kitab Suci (Yogyakarta: KANISIUS, 2009), 582.

${ }^{18}$ Ibid.

${ }^{19}$ R. Hutauruk, Lahir, Berakar dan Bertumbuh di dalam Kristus (Pearaja:Kantor Pusat HKBP, 2011), 75-76

${ }^{20}$ Ulrich Beyer, Memberi dengan Sukacita (Jakarta: BPK Gunung Mulia, 2011), 89-90.

${ }^{21}$ Istilah dikhususkan dalam bahasa Ibrani dipakai dengan istilah 'khe,rem.' Kata ini bersifat teknis menunjuk kepada apa yang harus dierahkan secara mutlak kepada Allah.
} 
yang diberikan harus betul-betul sesuai dengan ajaran Alkitab. Mungkin masih ada beberapa orang Kristen yang belum memahami secara jelas makna persembahan dan persembahan yang diindahkan Tuhan dan tidak diindahkan. Lewat karya tulis ini, semoga setiap orang yang membaca dapat memahami persembahan yang layak dihadapan Tuhan dan juga bisa menjadi berkat bagi orang lain.

Penulis menyampaikan teori mengenai persembahan Kain dan Habel, persembahan yang tidak diindahkan Tuhan dan diindahkan yang terdapat dalam Kejadian 4:1-16 kepada mahasiswa yang mengambil mata kuliah Psikologi umum kelas B dengan teori Teori Behavioristik. Teori Behavioristik adalah adalah sebuah teori yang dicetuskan oleh Gege dan Berliner tentang perubahan tingkah laku sebagai hasil dari pengalaman. Pengertian lainnya ialah perubahan tingkah sebagai akibat dari adanya interaksi antara stimulus dan respons. ${ }^{22}$ Dari teori ini yang diterapkan di kelas, mahasiswa ikut serta dalam praktek teori ini serta mereka juga menceritakan pengalaman sebelumnya dan dari pemaparan materi ini mahasiswa melakukan perubahan dalam kehidupannya mengenai persembahan yang diberikan kepada Tuhan.

\section{E T OD E}

Metode penulisan makalah ini adalah analisis data kualitatif yaitu menjelaskan data-data yang dikumpulkan sesuai dengan teori-teori yang dirangkum dari hasil penelitian. ${ }^{23}$ Selanjutnya dengan menggunakan model pembelajaran kooperatif berbasis media sosial. ${ }^{24}$ Dengan menggunakan metode 5P (Belajar berarti berubah) ${ }^{25}$ dengan tujuan untuk meningkatkan nilai-nilai karakter pada kecedasan anak usia dini. ${ }^{26}$

Ada lima (5) langkah yang dapat dilakukan secara detil mengenai tindakan aktivitas belajar yang dikenal dengan '5P-usaha yang tidak biasa', yaitu:

1. Penghubung - Pengalaman yang tidak biasa

(Semua perserta didik mengambil barang berharganya saat itu/dalam tas dan barang kesukaannya. Kemudian membayangkan jika barang berharga mereka atau barang kesukaan mereka diberikan kepada orang lain, apakah mereka memiliki hati yang ikhlas). Setelah itu narator akan membacakan ayat firman Tuhan dari Kej. 4:1-16 tentang persembahan Kain dan Habel. Sementara narator membaca ada juga drama singkat yang berperan sebagai Yesus, Kain dan juga Habel. Selama mendengar dan menyaksikan cerita ini pikiran, rasakan, dan lakukan bagian firman Tuhan tersebut.

2. Pelajaran - Usaha yang tidak biasa

Tuliskanlah satu kalimat pada sticker note yang dibagian setiap kelompok yang tidak biasa dilakukan dan yang mereka dapatkan dari cerita itu. Kemudian setiap anggota akan menjelaskan kata yang ditulis itu di sticker note.

\footnotetext{
${ }^{22}$ Moh. Suardi, Belajar dan Pembelajaran (Yogyakarta: Penerbit Deepublish, 2018), 106-107.

${ }^{23}$ Hengki Wijaya and Helaluddin Helaluddin, Analisis Data Kualitatif Sebuah Tinjauan Teori \& Praktik (Makassar: Sekolah Tinggi Theologia Jaffray Makassar, 2019).

${ }^{24}$ Hengki Wijaya and Arismunandar Arismunandar, "Pengembangan Model Pembelajaran Kooperatif Tipe STAD Berbasis Media Sosial," Jurnal Jaffray 16, no. 2 (October 6, 2018): 175-96, https://doi.org/10.25278/jj71.v16i2.302.

${ }^{25}$ Roland Walker, "Learning That LASTS," n.d., https://wycliffe.fi/wpcontent/uploads/2018/12/intro-to-learning-that-lasts-walker.pdf.

${ }^{26}$ Hengki Wijaya and Helaluddin Helaluddin, "Hakikat Pendidikan Karakter," 2018, https://repository.sttjaffray.ac.id/id/publications/269450/hakikat-pendidikan-karakter.
} 
3. Penerapan - Pikiran, perasaann, dan tindakan

Setiap kelompok berdiskusi, apa saja yang saudara pikirkan, rasakan, dan lakukan apabila saudara sebagai Kain dalam mengalami situasi itu. Serta menuliskan kesimpulan dari semua kelompok di papan tulis.

4. Perubahan - Bertindak sekarang

Dalam setiap kelompok diberikan kesempatan untuk saling menceritakan pengalaman mereka mengenai cara atau tujuan mereka memberikan persembahan pujian itu. Setelah itu barang berharga mereka atau barang kesukaan mereka saat itu diberikan kepada teman-teman atau orang lain yang paling dekat dengannya. Akhir langkah ini diberikan kesempatan kepada peserta yang ingin berbagi dengan pengalaman dan pelajaran baru dan apa yang mereka akan rubah dalam hidupnya.

5. Penutupan

Peserta dibagikan sticker not dan menuliskan komitmen perubahan dalam hidupnya mengenai memberi persembahan dengan ketulusan. Setelah itu menyanyi bersamasama dengan lagu "Ku Memberi dengan Sukacita" dan setelah itu berdoa bersamasama.

Tujuan pembelajaran ini dengan menggunakan Teori Behavioristik yaitu agar peserta dapat melihat kembali masa lalu yang dilakukan mengenai pemberian persembahan dan dibandingkan dengan pelajaran yang didaptkan dari kisah Kain dan Habel. Tentang persembahan yang layak di hadan Tuhan sedingga peserta membuat komitmen perubahan yang akan dilakukan yaitu memberi persembahan yang layak kepada Tuhan. meninggalkan masa lalu yang tidak sesuai dengan alkitabiah.

\section{HASIL DAN PEMBAHASAN}

Dari penerapan 5P yang telah dilakukan di dalam kelas kepada peserta maka peneliti memiliki hadil dari pengamatan dan aktivitas atau ikut serta kelompok, yaitu ketika peserta diberikan perintah untuk dilakukan yaitu mengambil barang yang paling mahal dan paling disukai perasaan mereka dapat dilihat dari ekspresi mereka bahwa mereka bahagia melihat barang itu. Namun, setelah diberitahukan bahwa jika barang tersebut diberikan kepada orang lain apa mereka ikhlas memberikannya, mereka tidak ada yang menjawa, mereka hanya tertawa. Jadi, bisa disimpulkan bahwa ketika mereka memberi, mereka memberi dengan memperhatikan atau memperhitungkan barang yang akan diberikan itu.

Saat peneliti membaca dan mempraktekkan kisah Kain dan Habel itu, peserta memperhatikan menggunakan pikiran, perasaan dan tingkah laku. Pikiran sangat diperlukan untuk dapat mengolah atau memikirkan apa yang sedang terjadi untuk mengerti maksudnya dan perasaan juga penting agar masalah yang terjadi saat itu dapat dilibatkan dengan masa lalu dan mengkaitkan jika diri sendiri terlibat pada kisah itu. Serta tingkah laku para tokoh juga diperhatikan, membandingkan perilaku yang bersifat postif dan negatif kemudian melibatkan kembali dengan pengalaman masa lalu untuk memperoleh perubahan terhadap tingkah laku sendiri.

Pada langkah pelajaran peserta dipersilahkan untuk menulis di sticker not tentang pendapat mereka mengenai peristiwa Kain dan Habel. Kemudian mereka menyampaikan hasil diskusi mereka, dan dari hasil tersebut dapat disimpulkan bahwa hal yang mereka peroleh dari pengamatan mereka yaitu persembahan Kain tidak layak dihadapan Tuhan karena memberi tidak dengan Iman atau ikhlas, sedangkan Habel persembahannya diindahkan karena ia memberi dengan ketulusan, dengan iman, serta memberikan yang 
terbaik yang dia miliki. Selain itu hal yang peserta juga peroleh ialah karena Kain merasa iri dengan apa yang diperoleh adiknya Habel sehingga Kain membunuh adiknya. Adanya rasa iri hati antar saudara mengenai pemberian kepada Tuhan yang diindahkan dan tidak diindahkan.

Setelah itu peniliti memberikan kembali sticker not untuk menuliskan pendapat mereka jika diri mereka diposisikan sebagai Kain. Mereka menjawab bahwa mereka juga akan merasa iri jika persembahan saudaranya sendiri diindahkan oleh Tuhan. Tapi ada juga yang menjawab bahwa jika persembahan tidak diindahkan oleh Tuhan maka perlu mengoreksi diri kembali yang sudah dilakukan apakah sesuai dengan kehendak Tuhan atau tidak. Selain meminta pendapat mereka jika mereka sebagai Kain, peneliti juga memberikan kesempatan untuk menuliskan apa yang mereka lakukan ketika mereka berperan sebagai Habel. Ada diantaranya menjawab bahwa dia akan tidak mengikuti perintah kakaknya sendiri, ada yang menjawab bahwa tidak akan memberi tahukan apa yang sudah dilakukan. Langkah ini dilakukan tetap menggunakan pikiran, perasaan dan tingkah laku.

Pada langkah perubahan ini berpusat kepada perubahan tingkah laku. Peserta diberikan kesempatan untuk menceritakan tentang pengalaman mereka mengenai pemberian persembahan. Ada diantara mereka memberi persembahan dengan nilai jumlah sedikit yang tidak sesuai dengan penghasil mereka, karena mereka merasa takut ketika mereka memberi persembahan mereka akan merasa kekurangan. Selain memberi dengan hasil jumblah sedikit, ada juga ketika menerima berkat tidak langsung disisihkan berkat itu yang ingin dimasukkan ke persembahan, mereka lebih mementingkan membeli kebutuhan mereka kemudian sisanya baru diberikan kepada persembahan. Serta ada juga yang memberi persembahan karena tidak mau memiliki rasa malu ketika mengikuti ibadah orang lain memberi persembahan sedangkan dia tidak, atau dengan kata lain mereka memberi persembahan agar orang lain dapat melihatnya. Setelah menceritakan masa lalunya itu, peneliti kembali menyuruh peserta untuk memberikan barang kesukaannya kepada orang lain dan akhirnya mereka memberinya dengan senyum walaupun soal hati tidak ada yang tahu, tetapi pemberian barang itu hanya sebagai contoh penerapan saja. Setelah itu peneliti memberikan kesempatan kepada mereka apa komitmen mereka yang ingin merka rubah dari sikap lamanya mengenai meberikan persembahan. Dari komitmen mereka itu, ada yang menuliskan bahwa mereka akan memberi persembahan kepada Tuhan dengan hati yang ikhlas, akan menyisipkan berkat yang didaptkan untuk mengembalikannya kepada Tuhan, selalu merasa bersyukur apa yang sudah dimiliki dan tidak memiliki rasa iri hati tentang apa orang lain yang dia dapatkan. Menulis komitmen itu perlu karena dapat mengarahkan atau memimpin terus bekerja dan berjanji untuk meraih apa yang belum pernah dicapai. ${ }^{27}$

Ketika semua langkah itu sudah dilakukan dan sudah menulis komitmen, peneliti kembali menjelaskan bagaimana pentingnya memberi persembahan sesuai dengan ajaran Alkitabiah. Bahwa memberi persembahan kepada Tuhan sebagai ungkapan syukur harus dengan hati yang ikhlas dan sukacita. Ketika seseorang menyerahkan persembahan, di dalamnya terkandung suatu pengakuan bahwa Tuhan Yesus telah memelihara kita dengan setia dan sempurna. Persembahan yang benar seharusnya diawali dengan kesediaan mempersembahkan diri dan hidup sepenuhnya kepada Tuhan, itulah persembahan yang hidup dan kudus. Seiring dengan hal itu, ketika orang Kristen hadir atau mengikuti ibadah di tengah-tengah gereja, di samping menyediakan hati dan pikiran untuk bersekutu dengan Tuhan, umat juga harus mempersiapkan persembahan yang akan diserahkan

${ }^{27}$ Thomas D. Zweifel, Ph. D., Communicate or Die: Mencapai Tujuan dengan Berbicara dan Mendengarkan (Jakarta: Gramedia Pustaka Utama, 2007), 88. 
kepada Tuhan. ${ }^{28}$ Selanjutnya langkah pembelajaran itu ditutupi dengan doa sekaligus mendoakan komitmen yang sudah dilakukan. Mendoakan komitmen agar dapat konsisten degan komitmen yang telah dibuat dan dapat melangkah bersama dengan Tuhan. ${ }^{29}$ Namun sebelum berdoa, peneliti beserta peserta terlebih dahulu menyanyikan lagu "Ku Memberi dengan Sukacita." Menyanyi sebelum berdoa dapat mengantarkan hati kita atau memperisapkan hati kita agar bisa lebih berfokus tentang doa kita dan apa yang akan didoakan nanti dapat dipahami.

\section{K E S I M P U L A N}

Persembahan adalah suatu pemberian kepada orang yang terhormat. Kata persembahan juga dapat diartikan dengan pembaktian diri, penyerahan diri, penghormatan, pengabdian atau minta perlindungan dari seseorang yang dianggap lebih kuat dari dirinya sendiri. Persembahan yang ditujukan kepada Tuhan adalah merupakan suatu tanda ucapan syukur. Sehingga perembahan yang diberikan harus merupakan persembahan yang terbaik dan diberikan dengan hati yang tulus atau ikhlas. Sejarah munculnya istilah "Persembahan" dimulai ketika "Kain dan Habel" mempersembahkan persembahannya kepada Allah (Kej. 4:1-16). Dimana Kain memberikan hasil dari tanahnya dan Habel memberikan hasil ternaknya yaitu domba. Tetapi persembahan Kain tidak diindahkan oleh Tuhan karena ia memberi tidak dengan Iman sedangkan Habel memberikan kepada Tuhan dengan hati yang beriman. Sehingga dari situ timbullah rasa iri hati Kain terhadap adiknya. Dari rasa iri hati itu, sehingga Kain membunuh adiknya sedniri yang persembahannya diindahkan oleh Tuhan.

Persembahan Kain tidak diterima karena ia memberi tidak dengan Iman tetapi persembahan Habel diindahkan oleh Tuhan karena ia memberi dengan Iman. Jadi, memberi persembahan itu harus dengan hati yang Iman yaitu dengan hati yang tulus. Banyak ayat pada Alkitab yang membahas mengnai pemberian persembahan yang layak dihadapan Tuhan. Persembahan merupakan suatu tanda sykur umat Allah yang layak diberikan kepada-Nya. Hal ini juga ditekankan dalam Ul. 16:16-17 dimana dikatakan 'Tuhan mengundang umat untuk menghadap hadirat Tuhan, tetapi jangan dengan tangan hampa.' Demikian juga dengan apa yang tertulis dalam Maz. 96:7-8 'Kepada Tuhan, hai suka-suka bangsa, kepada Tuhan sajalah kemuliaan dan kekuatan! Berilah kepada Tuhan kemuliaan nama-Nya, bawalah persembahan dan masuklah ke pelataran-Nya.' Jadi ikut beribah kepada Tuhan harus memberikan persembahan yang merupakan keharusan orang percaya. Dimana berkat yang diberikan kepada kita adalah iu ssemua pemberian Allah dengan proses yang berbeda-beda. Oleh karena itu, pemberian persembahan harus dengan Iman, tulus dan dengan hati yang penuh sukacita.

\footnotetext{
${ }^{28}$ Ulrich Beyer, Memberi dengan Sukacita (Jakarta: BPK Gunung Mulia, 2011), 89-90.

${ }^{29}$ Robert Coleman, The Master Plan of Evangelism: Rencana Pelayanan Kristus untuk Menjangkau Dunia (Jakarta: Katalis Media-Yayasan Gloria, 2018), 144.
} 


\section{K E P U S T A KA A N}

Andi, M. Setiawan. Pendekatan-Pendekatan Konseling Teori dan Aplikasi. Yogyakarta: Penerbit Deepublish, 2017.

Angela, Firmina Nai. Teori Belajar dan Pembelajaran Implementasi dalam Pembelajaran Bahasa Indonesia. Yogyakarta: Penerbit Deepublish, 2017.

Barth, C. Teologi PL I. Jakarta: BPK Gunung Mulia, 1988.

Beyer, Ulrich. Memberi dengan Sukacita. Jakarta: BPK Gunung Mulia, 2011.

Burkett, Larry. Mengatur Keuangan dengan Bijak. Bandung: Yayasan Kalam Hidup, 1993.

C., A. Kruyt. Keluar dari Agama Suku Masuk ke Agama Kristen. Jakarta: BPK Gunung Mulia, 2014.

C., G. van Niftrik dan B. J. Boland. Dogmatika Masa Kini. Jakarta: BPK Gunung Mulia, 2009.

Coleman, Robert. The Master Plan of Evangelism: Rencana Pelayanan Kristus untuk Menjangkau Dunia. Jakarta: Katalis Media-Yayasan Gloria, 2018.

Darmawijaya, St. Pr., Seluk Beluk Kitab Suci. Yogyakarta: KANISIUS, 2009.

D., Thomas Zweifel, Communicate or Die: Mencapai Tujuan dengan Berbicara dan Mendengarkan. Jakarta: Gramedia Pustaka Utama, 2007.

Douglas, D. J. Ensiklopedia Alkitab Masa Kini Jilid I. Jakarta: Yayasan Komunikasi Bina Kasih/OMF, 1992.

Gara, Nico. Menafsirkan Alkitab Secara Praktis. Jakarta: BPK Gunung Mulia, 2002.

I., Heri Budiyanto. Berbagai Terang Kristus. Jakarta: Pustaka Ekklesia, 2017.

Hutauruk, R. Lahir, Berakar dan Bertumbuh di dalam Kristus. Pearaja:Kantor Pusat HKBP, 2011.

Salim, Peter dan Yenny Salim. Kamus Bahasa Indonesia Kontemporer. Jakarta, Kodern English Press, 1991.

Suardi, Moh. Belajar dan Pembelajaran. Yogyakarta: Penerbit Deepublish, 2018.

Walker, Roland. "Learning That LASTS," n.d. https://wycliffe.fi/wpcontent/uploads/2018/12/intro-to-learning-that-lasts-walker.pdf.

Wijaya, Hengki, and Arismunandar Arismunandar. "Pengembangan Model Pembelajaran Kooperatif Tipe STAD Berbasis Media Sosial." Jurnal Jaffray 16, no. 2 (October 6, 2018): 175-96. https://doi.org/10.25278/jj71.v16i2.302.

Wijaya, Hengki, and Helaluddin Helaluddin. Analisis Data Kualitatif Sebuah Tinjauan Teori \& Praktik. Makassar: Sekolah Tinggi Theologia Jaffray Makassar, 2019. "Hakikat Pendidikan Karakter," 2018. https://repository.sttjaffray.ac.id/id/publications/269450/hakikat-pendidikankarakter. 